\title{
Foreign Institutional Investors: Fair-Weather Friends or Smart Traders?
}

\author{
Hari Venkatesh ${ }^{1} \cdot$ Jyoti Kumari ${ }^{2} \cdot$ Gourishankar S. Hiremath $^{1}$ (D ) Hiranmoy Roy ${ }^{3}$
}

Accepted: 22 February 2021 / Published online: 3 April 2021

(C) The Indian Econometric Society 2021

\begin{abstract}
We examine a theoretically robust but previously undocumented issue of what drives foreign portfolio investments into emerging markets. Foreign institutional investors (FIIs) are often blamed as fair-weather friends who pull out their investment at the first sign of trouble. Using a bottom-up approach, we explore this possibility. We demonstrate the influence of the firm-specific factors such as size, book to market ratio, the riskiness of the stocks, stock prices, dividend yield, liquidity, leverage, and earnings on the FII ownership. We find no evidence to show foreign investors as fair-weather friends. Instead, they are smart traders who follow a diligent investment strategy. We suggest reforms in corporate governance and improvement in financial fundamentals of the companies to attract FII ownership.
\end{abstract}

Keywords FII $\cdot$ Equity research $\cdot$ Corporate governance $\cdot$ Financials $\cdot$ Portfolio investment

JEL Classification F21 $\cdot \mathrm{G} 10 \cdot \mathrm{G} 11 \cdot \mathrm{G} 32$

\section{Introduction}

Foreign direct investment (FDI) and foreign portfolio investment (FPI) are the most important channels of capital flows into emerging and developing economies (EDEs). The higher returns and international portfolio diversification are primary drivers of FPI in the emerging stock markets (ESMs) (Solnik 1974). The remarkable increase in the FPI in ESMs and the consequences of integration of these economies

Gourishankar S. Hiremath

gshiremath@hss.iitkgp.ac.in

1 Department of Humanities and Social Sciences, Indian Institute of Technology Kharagpur, Kharagpur, India

2 IBS Hyderabad (ICFAI Foundation for Higher Education), Hyderabad, India

3 Department of Economics \& International Business, University of Petroleum and Energy Studies, Dehradun, India 
with the developed markets has prompted passionate debate in the international finance literature and policy circles. The FPI flows help bridge the gap between investment requirements and domestic savings in ESMs. However, the reversal of capital flows aggravates crises in the host markets (see Furman et al. 1998). Therefore, academics and policymakers alike raise concerns about the behavior of FPI flows. The foreign institutional investors (FII) ${ }^{1}$ are often accused as fair-weather friends who pull out investment at the first sign of trouble.

International finance literature predominantly focuses on the costs and benefits of investment in emerging markets to international investors. A strand of literature attempts to understand the relationship between FPI flows and host market returns (e.g., Froot et al. 2001; Richards 2005). Nonetheless, the research on what determines the business of foreign investors in EDEs is not probed before. The available research on determinants of portfolio investment emphasizes global factors (e.g., Taylor and Sarno 1997). Gupta and Gordon (2003) argue that FIIs follow a top-down approach relying more on macroeconomic and political factors to choose ESMs.

In contrast, FPI flows are more appropriately belong to the 'theory of the firm' than the global macro environment (Kang and Stulz 1997; Dahlquist and Robertsson 2001). These investors follow a bottom-up method to choose top quality firms and hardly be concerned about the macroeconomic factors (Sharma 2002). Kang and Stulz (1997) are the first to show the relevance of company-specific factors in investment decisions of foreign equity investors than the national portfolio investors. Lin and Shiu (2003) and Batten and Vo (2015) emphasize characteristics of the firms as drivers of foreign ownership of stocks in emerging markets. A smart investment strategy comprises top-down and bottom-up approaches, and global investors are no exception to this bottom line. A company analysis to pick stocks is as essential as selecting an emerging market based on the macroeconomic environment for portfolio diversification.

The financials of the company are the primary factors in investment decisions. Of late, corporate governance moved to the heart of investment decisions, especially among investors from developed markets (McKinsey 2002). Moreover, the financial performance of firms is positively associated with corporate governance (Mohanty 2003; Bebchuk et al. 2009). The growing literature in corporate governance indicates the reluctance of foreign investors to invest in stocks of companies with poor corporate governance (Mangena and Tauringana 2007). Hence, the investigation of the firm-level factors influencing the investment decisions of FPI is indispensable.

In this light, we employ a bottom-up approach to understand the determinants of foreign ownership of domestic stocks in EDEs such as India. We draw the sample from India, the second-fastest growing economy, for the empirical investigation. One of the critical features of the Indian stock market has been the rapid increase in the level of stock ownership by foreign investors as non-promoters from 3.25 percent to 29.02 percent in 2016 ("Recent trends in FPI ownership and stylized facts" section).

\footnotetext{
1 We denote FII as the foreign institutional investment and foreign institutional investors interchangeably as the context demands.
} 
Similarly, India is one of the few countries that witnessed FPI inflows during the postglobal finance crisis (GFC). We hypothesize that foreign investors follow the principle of investment analysis, and thus firm-level factors are vital for their choice of stocks. Further, we also test our proposition that foreign investors emphasize corporate governance in their decision to invest in host markets.

The previous work on emerging markets mainly perceives these markets as homogenous. Such a homogeneity bias (Hiremath 2017) hides the unique characteristics of the market and leads to incorrect inferences and policy prescriptions. Moreover, inferences from cross-country analysis are inapplicable to India due to its heterogeneity among the emerging markets. We use a comprehensive framework to include the information on the firm-level financials and corporate governance indicators to gain essential insights into the determinants of FPI flows. This holistic approach dispels the speculative views on foreign investors and offers practical and pragmatic implications for international investment. In this context, this study assumes significance.

We contribute to the literature in many folds. First, we present a set of new facts and trend analyses of FPI flow at the aggregate level and FII ownership of individual stocks. Our research helps understand the motives of foreign investors and business strategies in EDEs. Second, we incorporate both the firm-specific financial and corporate governance determinants of foreign ownership of Indian stocks. Previous researchers focused on macroeconomic factors. These studies especially suggest that the global environment alone influences the decisions of foreign investors to invest in ESMs. Third, we also add new firm-level factors such as a firm's visibility and protection of minority shareholders. The inclusion of essential variables expands the scope of our work and provides robustness to the results. Fifth, unlike previous empirical studies, we use the panel data framework to investigate the significant factors determining foreign ownership in Indian stocks. These empirical analyses offer a better understanding of investors' choices (Baltagi and Kao 2001; Hsiao 2007). Besides, we use alternative models to ensure the robustness and general applicability of the results.

We find that firm-specific factors are the primary drivers of the FII ownership in India. We also show that corporate governance practices influence global investors' decisions to invest in a particular stock. The rest of the paper is organized as follows: we present recent trends in FPI ownership of Indian stocks and stylized facts related to such flows in "Recent trends in FPI ownership and stylized facts" section. We discuss the empirical results in "Determinants of foreign ownership of domestic stocks" section and conclude our study with implication for policy and equity analysis in the last section.

\section{Recent Trends in FPI Ownership and Stylized Facts}

\section{Aggregate FPI Flows to India}

India has witnessed a surge of private capital flows during the post-liberalization period (Fig. 1). The flows increased from \$244 million in 1992-93 and reached $\$ 40,922$ million in 2014-15 (accounting for 168 times during 20 years). Nevertheless, FPI flows were volatile and reversed due to the East Asian currency crisis 


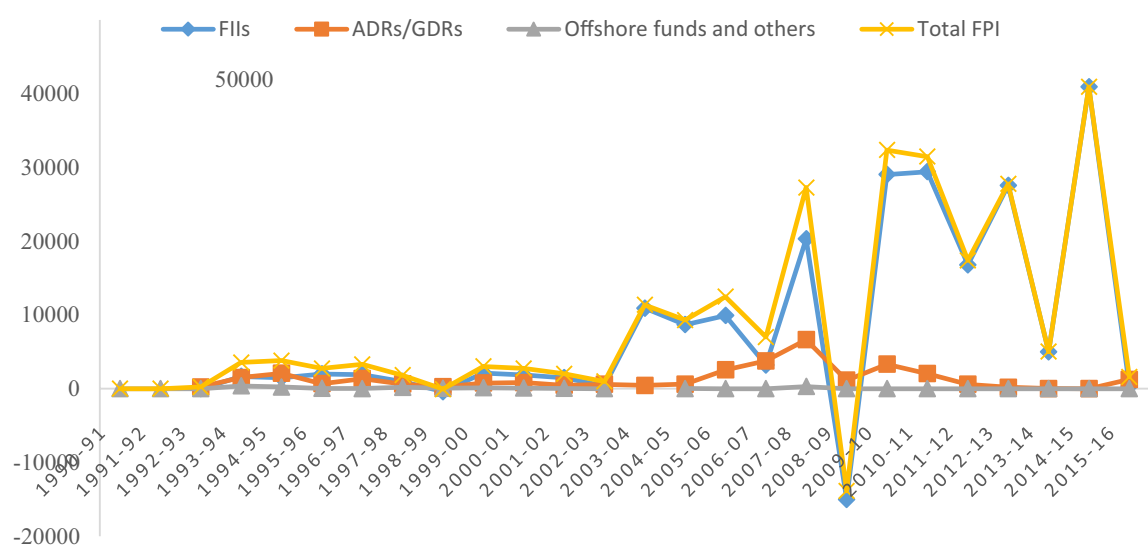

Fig. 1 Components of FPI flows to India. The figure shows the aggregate FPI flows to India and its component, namely FIIs, ADR/GDR, Offshore funds. The vertical axis is measures flows of US \$ in millions

(1997) and the dot-com bubble burst (2000-2002). The unprecedented outflows to the tune of $\$ 15,017$ million in 2008-09 due to GFC caused anxiety in the Indian stock market, and total portfolio investment flows to India were plunged further. After the intermediate slowdown, the FPI continued to flow into the Indian capital market in the post-crisis period. The FPI trends replicate all anecdotes of the business cycle with booms and busts.

Indian government allowed firms to raise capital by issuing depositary receipts such as American depositary receipts (ADRs) and Global depository receipts (GDRs) in 1992. Nevertheless, FII constitutes a significant portion of the FPI flows, whereas the share of ADRs and GDRs is meager. The 8735 FII firms registered with the Securities and Exchange Board of India (SEBI) are mainly from the United States $(34.53 \%)$, followed by Luxembourg (11.51\%), Canada (7.49\%), Mauritius $(6.87 \%)$, Ireland (5.80\%) and the UK (5.47\%) (Fig. 2). FII flows into India are mainly from developed countries, whereas sizeable portfolio investment comes from developing markets. FII from Mauritius, Cayman Island, Bahamas, Brunei, Bermuda, Liechtenstein, Republic of Slovenia, Guernsey, and Jersey also hold notable ownership of Indian stocks because of the tax advantages. ${ }^{2}$

\section{FII Ownership in India Stocks}

FII ownership in India's equity shares considerably increased during the study period and accounted for one-fourth of the total market value. The FIIs hold a significant share in non-promoter shareholdings. As per the shareholding data, FIIs held ownership in 4281 firms between 2001 and 2016 (Table 1). The distribution of FIIs shareholding is less than one percent in 2663 firms, whereas such holding between

\footnotetext{
2 These countries are considered as tax havens.
} 


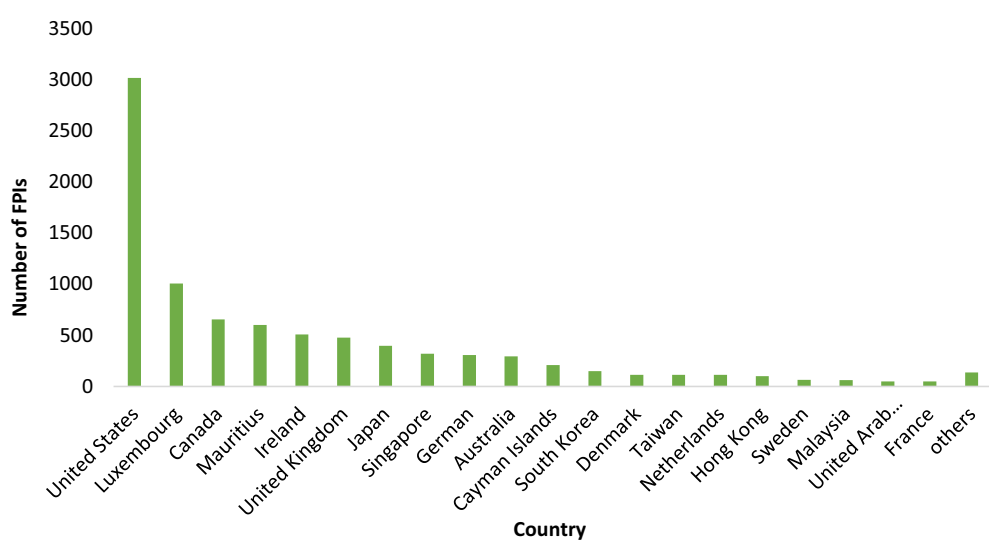

Fig. 2 Country-wise distribution of registered FPI firms in India. This figure presents the country-wise registered FPI firms in India. The total registered FPI firms are 8735 as of September 2017

Table 1 Percentage distribution of FII ownership of firms

\begin{tabular}{lcc}
\hline $\begin{array}{l}\text { Percentage of FII owner- } \\
\text { ship (\%) }\end{array}$ & Number of firms & $\begin{array}{l}\text { Percent of } \\
\text { total firms }\end{array}$ \\
\hline Less than one & 2698 & 63.02 \\
$1-10$ & 1164 & 27.19 \\
$10-20$ & 327 & 07.64 \\
$20-30$ & 69 & 01.61 \\
More than 30 & 23 & 00.54 \\
Total & 4281 & 100.00 \\
\hline
\end{tabular}

This table presents the distribution of FII ownership in the non-promoter shareholding of the firm's total equity

20 and 30 percent is concentered in 63 firms. The HDFC Ltd., India Bulls Housing Finance Ltd., IDFC Ltd., Geodesic Ltd., ICICI Bank Ltd. are among the top 10 companies in which FII have substantial shareholdings as a non-promotor (Table 2).

The sectoral composition of FII ownership of equity reveals a more significant share of FII holding in the financial sector than that of the non-financial and irrigation sectors (Fig. 3). The stocks in the financial sector attract foreign investors because of higher returns when the market is bullish. The growing trend of FII ownership was steady until 2007-08 but began to plunge due to the recession in 2008 . From 2009 to 2016, the FII ownership in India's equity has become stable. On the other hand, the average FII ownership in the irrigation sector is negligible (less than one percent). Foreign investors primarily invest in the manufacturing sector than other non-financial sector firms such as mining, electricity, services, and construction and real estate (Fig. 4).

Nonetheless, between 2003 and 2008, electricity firms are the primary recipients of the FII investment, and the construction and real sector dominated their portfolios between 2008 and 2010. The loss of returns on the financial sector as many stocks 


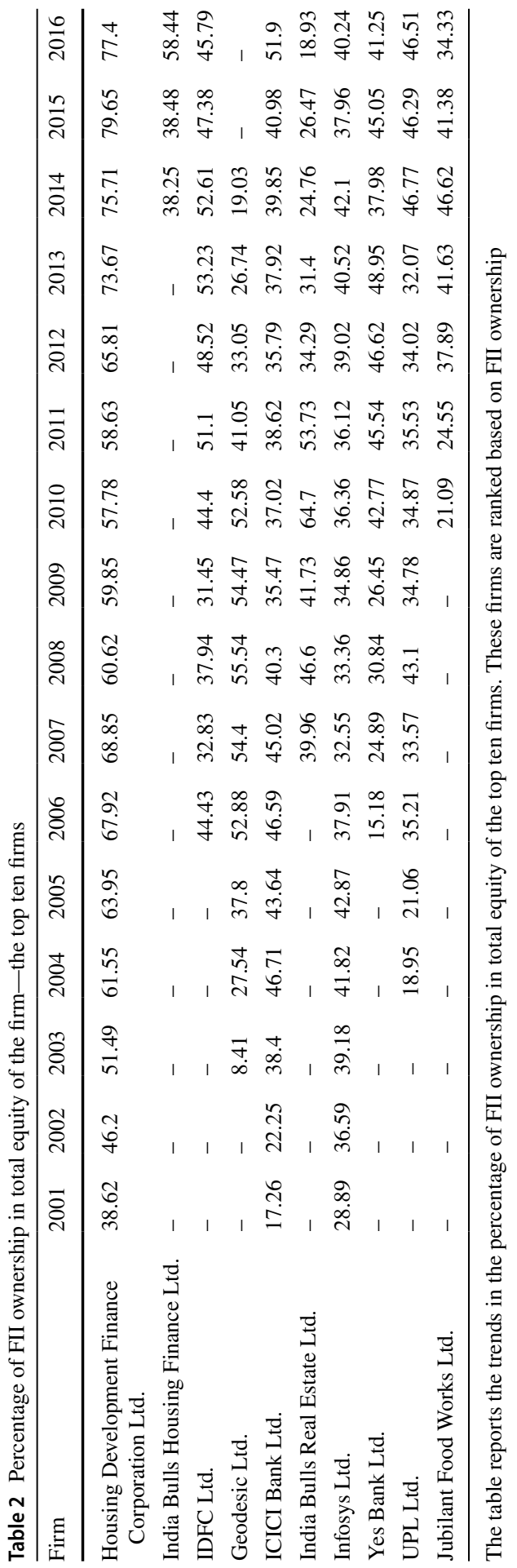




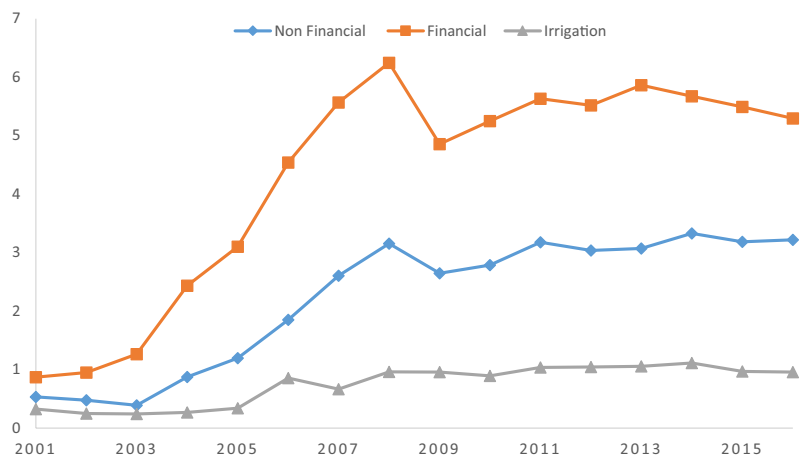

Fig. 3 Sector-wise classification of FII ownership. This figure shows the distribution of FII ownership sector-wise. The average FII ownership as a non-promoter share in total shares (\%) is measured on the vertical axis

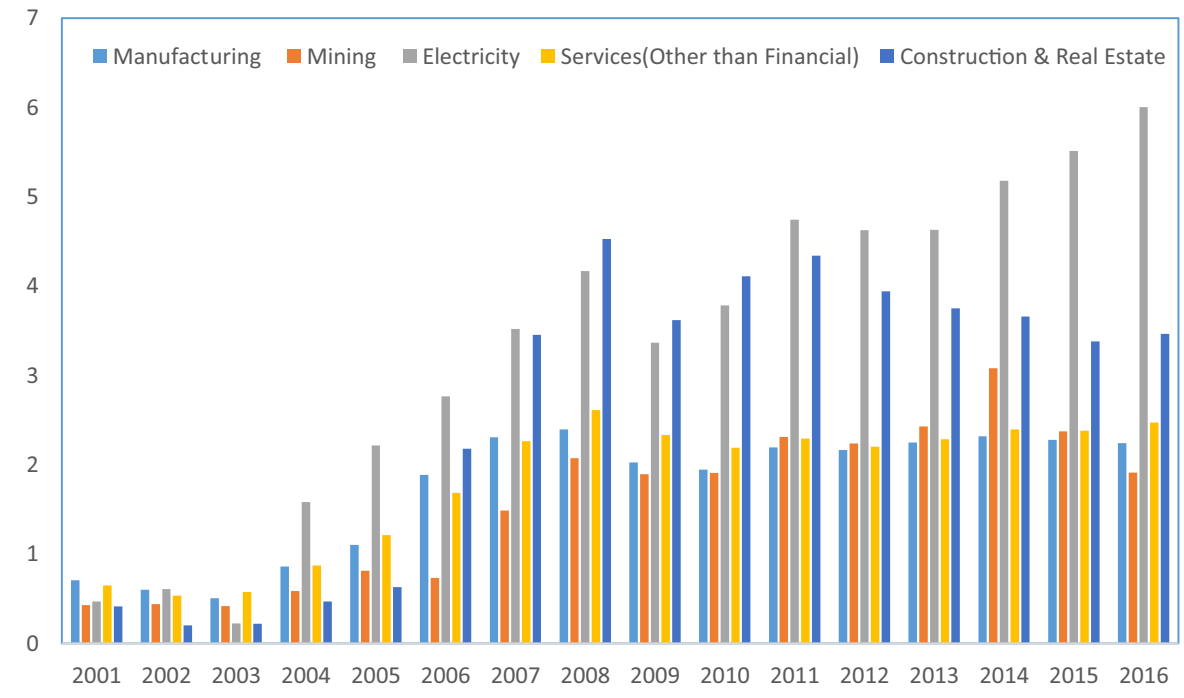

Fig. 4 FII Ownership in the non-financial sector. This figure presents the distribution of FII ownership in the non-financial sector, such as manufacturing, mining, electricity, services, and construction and real estate. The average FII ownership as a non-promoter share in total shares (\%) is measured on the vertical axis

crashed during the period explains the change. Foreign investors also prefer financial service firms. The FII ownership in the banking sector comprises 85 percent of the total investment in the financial sector (Fig. 5). 


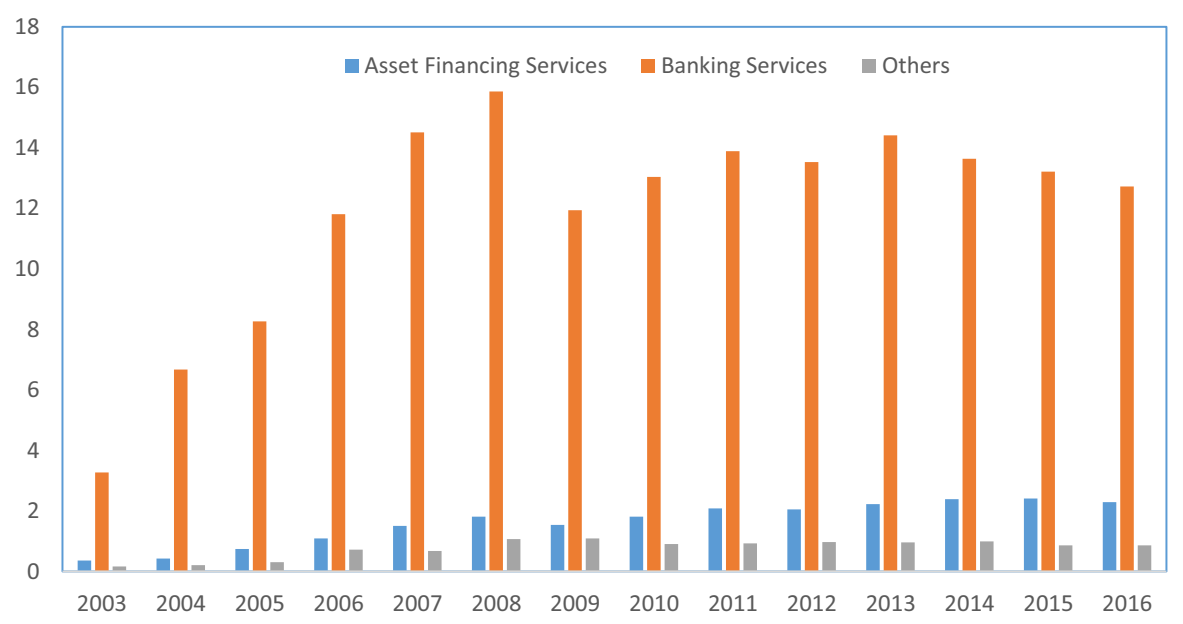

Fig. 5 FII ownership in the financial service sector. This figure represents the FII holdings of 721 financial service sector firms as a non-promoter investment. The average FII ownership as a non-promoter share in total shares $(\%)$ is measured on the vertical axis

\section{Determinants of Foreign Ownership of Domestic Stocks}

The foreign investors ownstocks of 4281 firms as non-promoters in India. However, the FII ownership of a majority of the firms was limited to a couple of years. Many firms do not hold FII ownership all the years. Thus, the sample is largely unbalanced due to missing information or FIIs not investing in stock for more than a year. Therefore, we selected all those firms in which foreign ownership is for a minimum of 9 years to avoid the weakly unbalanced data for the panel regression. ${ }^{3}$ The selection of firms is based on the availability of the data and a chosen statistical design. The analysis of FII sample data suggests a diversity of data in terms of sectors, size, and percentage of ownership (Figs. 2, 3, 4, 5). The descriptive statistics of the sample also suggest cross-sectional variability of the data (Tables 1 and 4). The purpose of current research is defeated if the value of the dependent variable is missing. Centre for Monitoring Indian Economy Private Limited (CMIE) Prowess and Bloomberg collate the balance sheets of the companies. The data on FII ownership of stocks is not available for all the years, and several values are missing. The reason for missing value-value missing due to technical error or FII does not own the stocks for a particular year is not available in the databases. The present case is more of a randomly missing values problem than the selection bias. Addressing the missing values by imputing a related time series or basing the entire estimation on bootstrapped samples with accept/reject criteria is not advisable to the current research question. Moreover, such exercises entail some assumptions and lead to severe bias.

\footnotetext{
3 The criteria of a minimum of nine years provide sufficient information on FII ownership in Indian stocks and overcome the problem of weak unbalance panel.
} 
When the reason for non-response is ignorable, standard panel methods can be applied for consistent estimations. In the present case, the data on FII is missing due to non-response. Hence, we can estimate the standard panel regression. As illustrated by Verbeek and Nijman (1996), our conditioning does not affect the distribution of interest, and the selection rule is ignorable. In such a case, the selection process is ignorable when making inferences without affecting the consistency or efficiency of the standard estimators (Verbeek and Nijman 1996).

The percentage distribution of the FII ownership in firms shows that the sample is not skewed, and descriptive statistics confirm the diversity (Tables 1 and 4). The alternative statistical designs are susceptible to biases. For instance, a probit model leads to misleading inferences in the absence of information on missing value (see Wooldridge 2010; Baltagi 2021). ${ }^{4}$ Moreover, such an analysis is less meaningful in the absence of no information on whether the value is missing or FIIs do not own stocks for a particular year. Our sample selection method is consistent with Kang and Stulz's (1997).

However, sample selection bias may still be present in the sense of Renders et al. (2006). Hence, the results of the present study need to be understood in light of such biases. The study covers the period from 2001 to 2016, and the final sample comprises 1078 firms. The availability of data dedicates the study period and choice of the sample. We obtained firm-level data from the CMIE Prowess database.

\section{Firm-Specific Factors}

We examine the firm-specific factors that determine the FII investment in a particular company. The examination of the issue necessitates time-series and crosssectional dimensions. Accordingly, panel data econometric modeling appropriately gives attention to these two dimensions of the data. The use of panel data provides the flexibility of econometric modeling and the ability to control for unobserved heterogeneity (Verbeek 2021). The motivation for using panel data is to solve the omitted variables problem (Wooldridge 2010). The panel regression mitigates omitted variable bias when information on variables correlated with both the regressors and regressand if these variables are constant in the time dimension or across entities (Baltagi 2021). The panel data on firms can minimize estimation biases arising from aggregating groups into a single time series (Sul 2019). Panel data contains more information, more variability, and more efficiency than pure time-series data or cross-sectional data (Hsiao 2014). Panel data framework includes both cross-section and time series. Thus the number of observations is greater than cross-section and time-series alone. Firm-level FII determinants enjoy more significant heterogeneity as panel framework varies across a cross-section and over time. Such greater heterogeneity increases efficiency, lowers the collinearity among the explanatory

\footnotetext{
${ }^{4}$ CMIE and Bloomberg collate the balance sheets and financial statements of the firms. CMIE Prowess does not provide any information on whether the missing value is due to no investment or random missing information. The final sample, therefore, is subject to the availability of data and missing values are random.
} 
variables, and increases the degrees of freedom and consistency (Wooldridge 2010). The panel regression, therefore, is the most appropriate method to understand the firm-level determinants of the FII ownership of stocks. We estimate the following panel regression equation to examine firm-level determinants:

$$
\begin{aligned}
F I I_{i, t}= & \alpha_{i}+\beta_{1} \text { Size }_{i, t}+\beta_{2} B M_{i, t}+\beta_{3} \text { Risk }_{i, t}+\beta_{4} D Y_{i, t}+\beta_{5} C P_{i, t}+\beta_{6} C R_{i, t} \\
& +\beta_{7} D E_{i, t}+\beta_{8} E X P S_{i, t}+\beta_{9} E P S_{i, t}+\beta_{10} R O A_{i, t}+\beta_{11} F V_{i, t}+\beta_{12} F D I_{i, t}+\beta_{13} A g e_{i, t}+\varepsilon_{i, t} .
\end{aligned}
$$

In Eq. (1), the dependent variable $F I I_{i t}$ denotes the FII ownership of firm $i$ at time $t$. The right-hand side variables are firm-specific factors selected based on their theoretical relevance and availability of data (Table 3 ). The theoretical framework for the empirical analysis of firm-specific factors is based on home bias, asymmetric information, and agency problem models. ${ }^{5}$ The firm-level factors help foreign investors to overcome the problem of asymmetric information. FII also benefits from the corporate governance of companies to factor the agency costs in investment decisions.

a. Firm's size (Size): Modigliani-Miller (1958) theorem presumes a perfect capital market in which the internal and external capital are the perfect substitutes for the firms. The theorem imperatively argues that the larger the firm, the higher the investments. Smaller firms suffer from asymmetric information problems, which raises the cost of capital. The agency cost is also more for smaller firms (Devereux and Schiantarelli 1990; Kadapakkam et al. 1998). Firm size, therefore, is expected to be positively related to FII ownership.

b. Book-to-market ratio $(B M): B M$ is the ratio of book value per share to an adjusted closing price of the firm. The theoretical relationship between $B M$ and investment decision is ambiguous. A high $B M$ indicates low earnings on the firm's assets, whereas a low BM suggests higher earnings (Fama and French 1992). When investors prioritize the persistence in earnings, $B M$ is inversely related to the FII ownership. However, a positive relationship is expected between $B M$ and average returns when relative profitability is the source of a common risk factor in returns (Fama and French 1995a, b).

c. Market risk (Risk): Market risk of a particular stock or security (Firm's beta value) measures the volatility. Theoretically, systematic risk and investment decisions are positive and linearly related (Sharpe 1964; Lintner 1965). These studies show that higher systematic risk suggests higher expected returns of stock and worthy of owning it. Solnik (1974) argued that risk is comparatively low in the internationally diversified portfolio than in domestic portfolios.

d. Dividend yield $(D V): D Y$ is the financial ratio that measures the cash dividends paid to shareholders relative to the market value per share. The theoretical works of Miller and Modigliani (1961) imply the negative relationship between DY and returns. The high and low $D Y$ ratios signal a fall and rise in stock returns suggesting a negative association between $D Y$ and FII ownership. However, the dividend puzzle continued to be a conundrum (Brealey et al. 2017).

\footnotetext{
${ }^{5}$ For an excellent and concise review, see Khanna et al. (2005).
} 


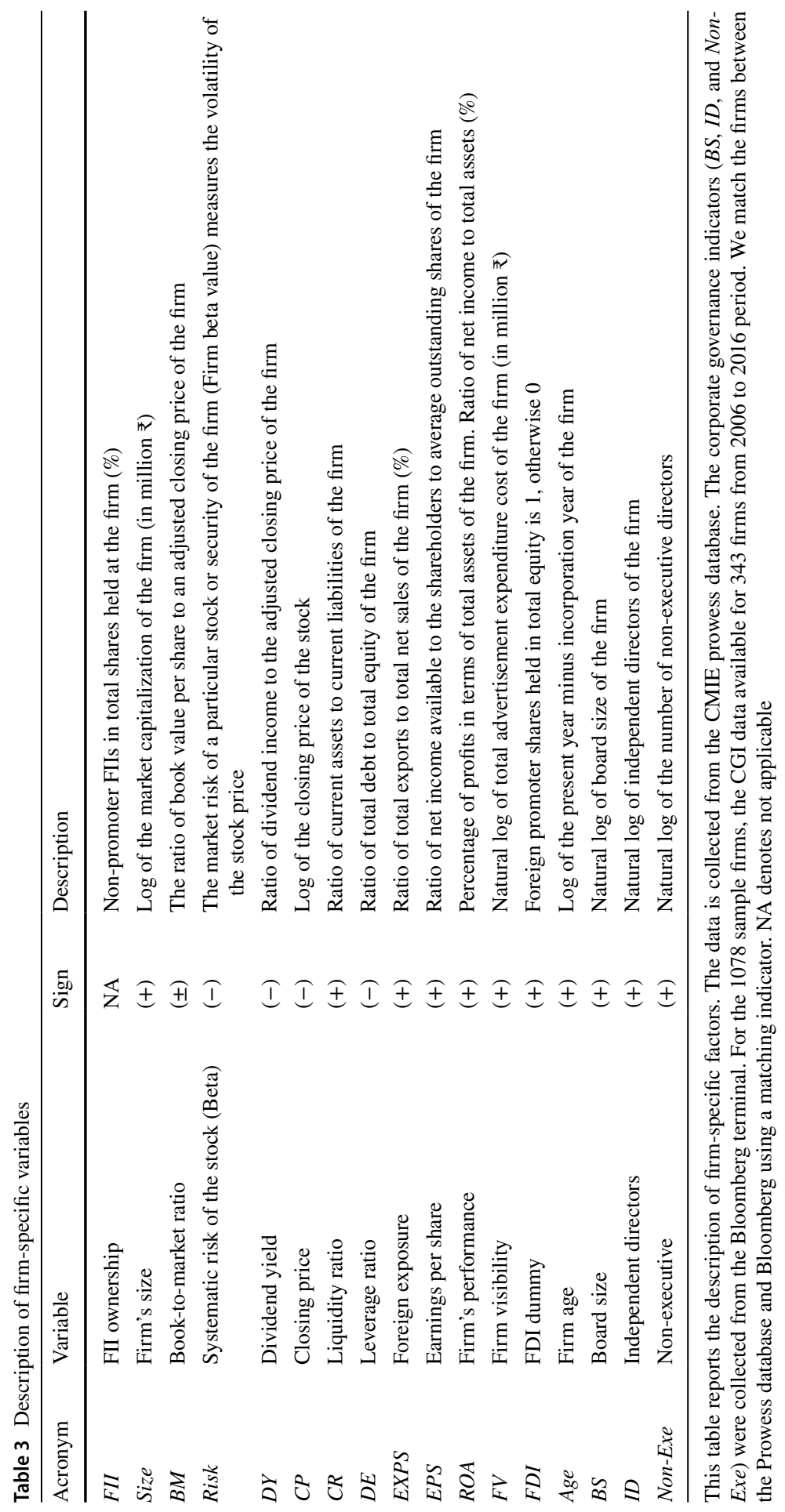


Table 4 Descriptive statistics of firm-specific factors

\begin{tabular}{|c|c|c|c|c|c|c|c|c|}
\hline Variable & $\mathrm{N}$ & Mean & Median & St.Dev & Min & Max & Skewness & Kurtosis \\
\hline$F I I$ & 13,928 & 7.30 & 3.29 & 9.60 & 0.00 & 79.65 & 1.93 & 7.61 \\
\hline Size & 15,418 & 7.96 & 7.96 & 2.43 & -0.04 & 15.42 & 0.02 & 2.75 \\
\hline$B M$ & 15,419 & 2.93 & 1.04 & 7.80 & -19.49 & 49.49 & 3.41 & 20.35 \\
\hline Risk & 14,760 & 1.00 & 0.98 & 0.42 & -2.40 & 3.39 & 0.20 & 4.74 \\
\hline$D Y$ & 15,419 & 0.76 & 0.01 & 2.72 & 0.00 & 20.12 & 5.53 & 35.88 \\
\hline$C P$ & 15,419 & 4.17 & 4.24 & 1.74 & -2.41 & 10.57 & -0.21 & 2.90 \\
\hline$C R$ & 16,669 & 2.18 & 1.21 & 6.01 & -2.78 & 149.57 & 13.92 & 249.99 \\
\hline$D E$ & 15,537 & 1.33 & 0.64 & 2.35 & 0.00 & 16.41 & 4.14 & 23.39 \\
\hline EXPS & 16,628 & 17.71 & 3.64 & 27.20 & 0.00 & 99.85 & 1.71 & 4.82 \\
\hline$E P S$ & 15,409 & 10.98 & 5.32 & 24.80 & -61.00 & 126.48 & 1.68 & 9.55 \\
\hline$R O A$ & 16,533 & 3.04 & 3.32 & 14.71 & -537.94 & 263.10 & -6.33 & 191.18 \\
\hline$F V$ & 9524 & 2.40 & 2.48 & 2.73 & -2.30 & 10.56 & 0.05 & 2.15 \\
\hline$F D I$ & 17,248 & 0.23 & 0.00 & 0.42 & 0.00 & 1.00 & 1.29 & 2.66 \\
\hline Age & 16,314 & 3.25 & 3.22 & 0.70 & 0.00 & 5.03 & -0.54 & 4.41 \\
\hline$B S$ & 2447 & 1.85 & 2.20 & 0.90 & 0.00 & 3.09 & -1.35 & 3.31 \\
\hline$I D$ & 2376 & 1.55 & 1.61 & 0.41 & 0.00 & 2.48 & -1.31 & 5.90 \\
\hline Non-Exe & 2324 & 1.75 & 1.95 & 0.60 & 0.00 & 2.83 & -1.80 & 6.07 \\
\hline
\end{tabular}

Variables as defined in Table 3. St.Dev denotes standard deviation

e. Closing price $(C P)$ : Theoretically, the closing price is an important determinant of FII flows as investors prefer a stock with potentially higher returns. The models of Froot et al. (2001) and Richards (2005) suggest a positive relationship between FII flows and closing prices of the stock. Dhamija (2008) empirically shows such a positive relationship in the case of India.

f. Liquidity ratio $(C R)$ : Finance theory suggests an influence of stock liquidity on corporate investment decisions. Amihud and Mendelson (1986) postulate a direct relationship between stock liquidity and a firm's value. As assets are discounted at the lower cost of capital, the liquidity of the firm improves. Brennan and Subrahmanyam (1996) and Easley and O'Hara (2004) support the liquidity premiums in stock returns. The liquidity ratio is thus expected to be directly related to the FII ownership.

g. Leverage ratio $(D E)$ : The ratio of total debt to the firm's total equity indicates a firm's leverage. According to the pecking order theory, leverage adversely affects the firm's performance. A leverage firm risks the investment of shareholders who are residual claimants. Further, Batten and Vo (2015) assert a negative relationship between leverage and foreign ownership; foreign investors prefer to invest in low leverage firms.

h. Foreign exposure (EXPS). The ratio of exports to total sales (EXPS) is an important measure of the firm's international exposure. Investors prefer stocks of those companies which they know better (Merton 1987a, b). Global investors are expected to be more familiar with export-oriented firms than non-export firms 
(French and Poterba 1991). Hence, foreign exposure to the firm is expected to attract FII inflows.

i. Earnings per share (EPS): EPS is the ratio of net income minus dividends on preferred stock to an average of outstanding shares of a firm. EPS is an indicator of the financial health of the firm. We expect a positive relationship between EPS and FII ownership. Such a proposition relies on implied cost equity models (see Claus and Thomas 2001; Fama and French 2002).

j. Firm's performance $(R O A)$ : Return on assets $(R O A)$ is the percentage of net income to total assets. $R O A$ shows how efficiently a firm utilizes its resources to earn profits (see Galo 2016). It overcomes the drawback of size and returns on equity indicators of a firm's performance. Investors, including foreign investors, prefer to invest in stocks with higher ROA.

k. Firm visibility $(F V)$ : We measure a firm's visibility based on advertisement expenditure, news coverage, and product usage. The increased expenditure on advisement and news coverage leads to more publicity and visibility, attracting the FIIs. Merton's (1987a, b) model illustrates how investors prefer stocks they are aware of and familiar with. The home bias and information asymmetry are stylized facts of foreign investment, and news coverage and publicity familiarize these investors about the company in the sense of Merton (1987a, b). We expect a positive relationship between a firm's visibility and FII ownership. This priori is consistent with the theory of asymmetric information.

1. Foreign promoter ownership (FDI): FDI promoter ownership leads to greater integration in international capital markets and notable international exposure of a firm. Hence, FIIs prefer to invest in the firms where FDI investors have promoter ownership. Kaminsky et al. (2001) illustrate that the FII ownership is primarily driven by herd behavior and similarity. Edison and Warnock (2003) show that the FII investors follow peers and prefer the markets in which already direct investment is made primarily to overcome asymmetric information in emerging markets. The behavioral aspects such as herd behavior and group identity induce the FIIs to invest in those companies in which FDI ownership exists (Coval and Moskowitz 1999). We employ a dummy variable to denote the presence of foreign promoter ownership. When a firm holds more than 25 percent of the FDI in total equity, the dummy takes the value of one and zero otherwise. We expect a higher level of FDI ownership in a firm induces FIIs to own its stock.

m. Age (Age): This factor is crucial in investors' equity investment decisions, mainly when the market is characterized by asymmetric information. Theoretical literature, especially evolutionary economics, suggests that financial performance is positively related to the firm's age. The age of company influences performance through routinization, accumulated reputation, and organizational rigidity (Coad et al. 2018). Hence, age is expected to influence FII ownership directly.

The descriptive statistics in Table 4 show that the average value of FII ownership is 7.30 percent of the firm's total equity, while the maximum is 79.65 percent over the period; the FII ownership widely differs across the sample firms. FII ownership has high cross-sectional variability ranging from 0 to 79.65 , with a median 
value of 3.29. Several explanatory variables have mean values that deviate from the medians. The skewness statistics suggest that all variables are positively skewed, whereas the book-to-market, return on asset, and age are negatively skewed. Kurtosis statistics show that all variables have peaks and are non-normally distributed. The Jarque-Bera test statistic further confirms the non-normal distribution of the data series (Table 4). ${ }^{6}$

We find all explanatory variables significantly correlated with FII ownership except the $C R$ and $F D I$ (Table 5). The low pairwise correlations among the explanatory variables suggest independence among these variables. Further, the variance inflator factor (VIF) statistics suggest no multicollinearity among the regressors. ${ }^{7}$ The Fisher type augmented Dicky-Fuller (ADF), and the Phillips-Perron (PP) panel unit root statistics confirm the stationarity of the variables (Table 6). We estimate the fixed and random-effect models to understand the firm-level determinants of FII ownership. The intercept of the fixed-effect model is time-invariant but varies across the firms. However, the random-effect model considers both individual and time effects. The Hausman (1978) and Sargan (1958)-Hansen (1982) test statistics suggest the relevance of the fixed-effect models for the firm-level analysis. The residuals are normally distributed.

In Table 7, we report the main results of the determinants of firm-specific factors. The size of the firm reflects the aggregate valuation of the firm. The coefficient of size is positive and statistically significant, indicating that large firms attract greater FII ownership. The result is in line with the theoretical proposition that foreign investors favor large firms over smaller firms because the former firms suffer less from asymmetric information than the latter (Merton 1987a, b; Huberman 2001). Large size firms allow better diversification and efficiently use the resources. The economies of scale achieved by large firms result in higher sales (Gompers and Metrick 2001; Dahlquist and Robertsson 2001). Besides, large size firms are internationally well recognized than that of small firms. Kang and Stulz's (1997) model illustrates the strong bias of foreign investors against smaller firms. Our findings on the size as the vital determinant corroborate the finding of Dahlquist and Robertsson (2001), Lin and Shiu (2003), and Batten and Vo (2015).

We use the book-to-market ratio $(B M)$ to proxy the profitability and growth of the firm (Fama and French 1995a, b). We find the positive and statistically significant influence of $B M$ on FII ownership; the high value of the $B M$ suggests the stock's undervaluation and, thus, potentially a growth stock. Such growth stocks attract investors. Liljeblom and Löflund (2005) and Batten and Vo (2015) also document similar results for Finnish and Vietnamese stock markets, respectively. Nevertheless, our results contradict the findings of Lin and Shiu (2003), who argue that institutional investors hold ownership in firms with low $B M$ (overvaluation) because of asymmetric information. According to these authors, low $B M$ firms have high earnings than high $B M$ firms, and therefore, foreign investors prefer to hold stocks of

\footnotetext{
${ }^{6}$ We have transformed the data into a required form such as log, Z-core (standardization), and Box-Cox transformation as per the panel estimation prerequisite.

${ }^{7}$ VIF results are not reported to save the space.
} 


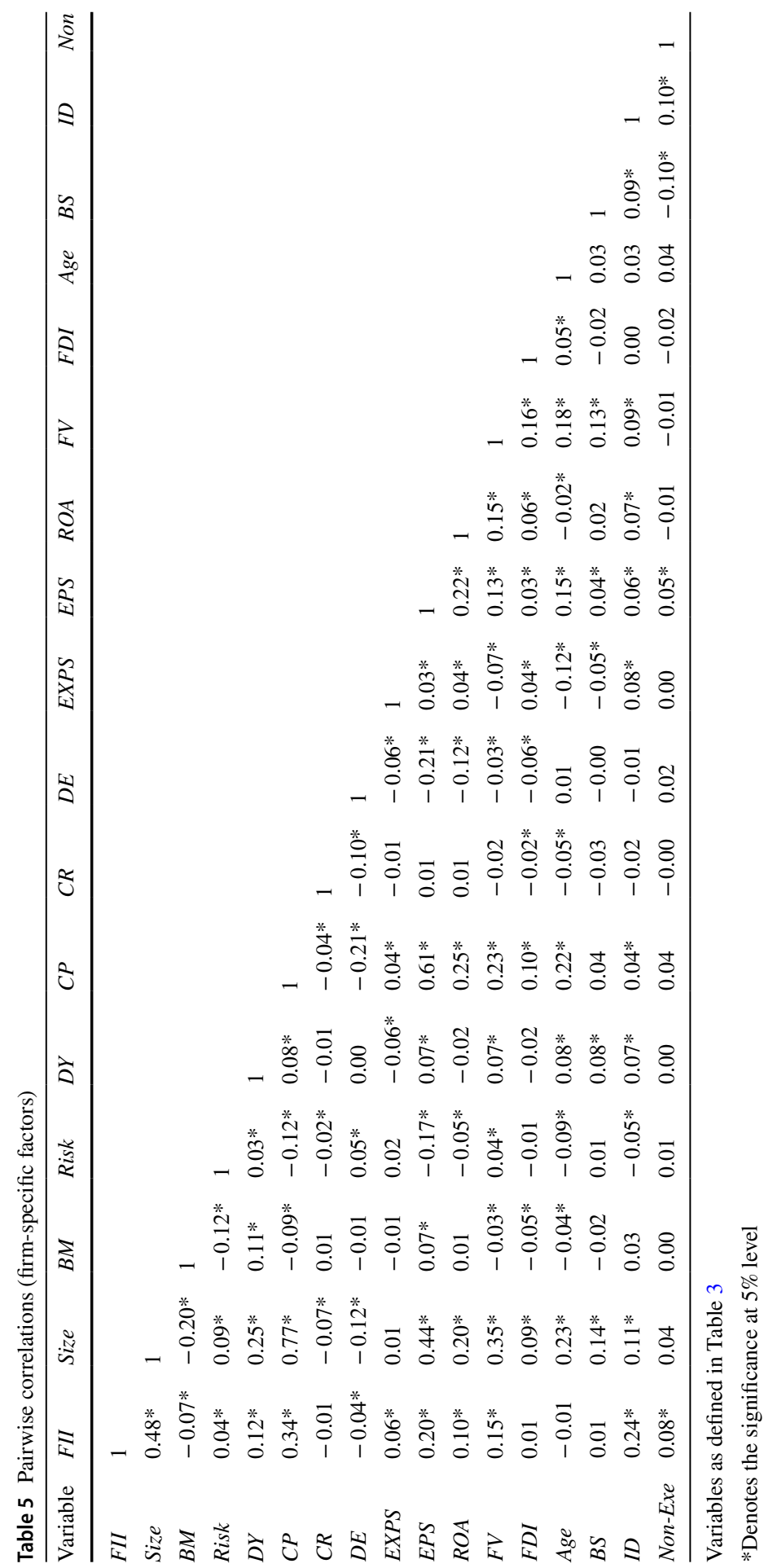


Table 6 Panel unit root statistics

\begin{tabular}{llc}
\hline Variable & Augmented Dicky Fuller & Phillips-Perron \\
\hline FII & $3454.86^{*}$ & $3274.12^{*}$ \\
Size & $2871.87^{*}$ & $2819.49^{*}$ \\
$B M$ & $6860.47^{*}$ & $6198.40^{*}$ \\
Risk & $2311.20^{* *}$ & $2284.31^{* *}$ \\
$D Y$ & $5479.11^{*}$ & $5656.10^{*}$ \\
$C P$ & $7855.42^{*}$ & $10,325.3^{*}$ \\
$C R$ & $4195.32^{*}$ & $4171.13^{*}$ \\
$D E$ & $4281.10^{*}$ & $4094.97^{*}$ \\
EXPS & $3716.34^{*}$ & $3489.53^{*}$ \\
EPS & $4357.25^{*}$ & $3983.13^{*}$ \\
ROA & $5044.69^{*}$ & $5044.69^{*}$ \\
FV & $2905.84^{*}$ & $2907.75^{*}$ \\
Age & $7400.00^{*}$ & $7400.00^{*}$ \\
$B S$ & $2080.78^{*}$ & $2080.78^{*}$ \\
$I D$ & $1059.20^{*}$ & $1059.20^{*}$ \\
Non-Exe & $1458.02^{*}$ & $1458.02^{*}$ \\
\hline
\end{tabular}

Variables as defined in Table 3. Lags are selected based on the Schwarz information criterion (SIC).

$*$ and $* *$ indicate statistical significance at $1 \%$ and $5 \%$ level, respectively

these firms. In India, foreign investors identify the undervalued stocks that offer better returns in the future. Thus, they push the price towards fundamental value in the market by incorporating the information.

Further, we find an inverse relationship between risk and FII ownership. This result reflects how the high riskiness of the firms discourages foreign investors. This evidence contradicts some previous research and conventional theoretical models of Sharpe (1964) and Lintner (1965) but supports the view that foreign investors prefer large firms than the high-risk small firms despite expected higher returns. Our evidence on risk is consistent with the empirical works of Kang and Stulz (1997) and Liljeblom and Löflund (2005). The inference also draws support from the finding on the size and FII relationship.

In the case of dividend yield, we find a negative relationship indicating the preference of foreign investors for the low dividend paid stocks over the high dividend yield stocks. Such choice is due to the higher future growth of low dividend stocks and tax advantage accrued to these stocks. Moreover, the institutional investors are concerned about the holding ownership rather than the dividend of a particular stock. The evidence consists of theoretical predictions (Miller and Modigliani 1961; and Brealey et al. 2017). Such a relationship is also documented for Swedish and Finnish markets (Dahlquist and Robertsson 2001; Liljeblom and Löflund 2005).

We find an inverse relationship between the closing price of the stock and FII ownership. This result suggests that FII investors choose stocks with low prices as they consider them as undervalued, which offer better returns in the future. In other 


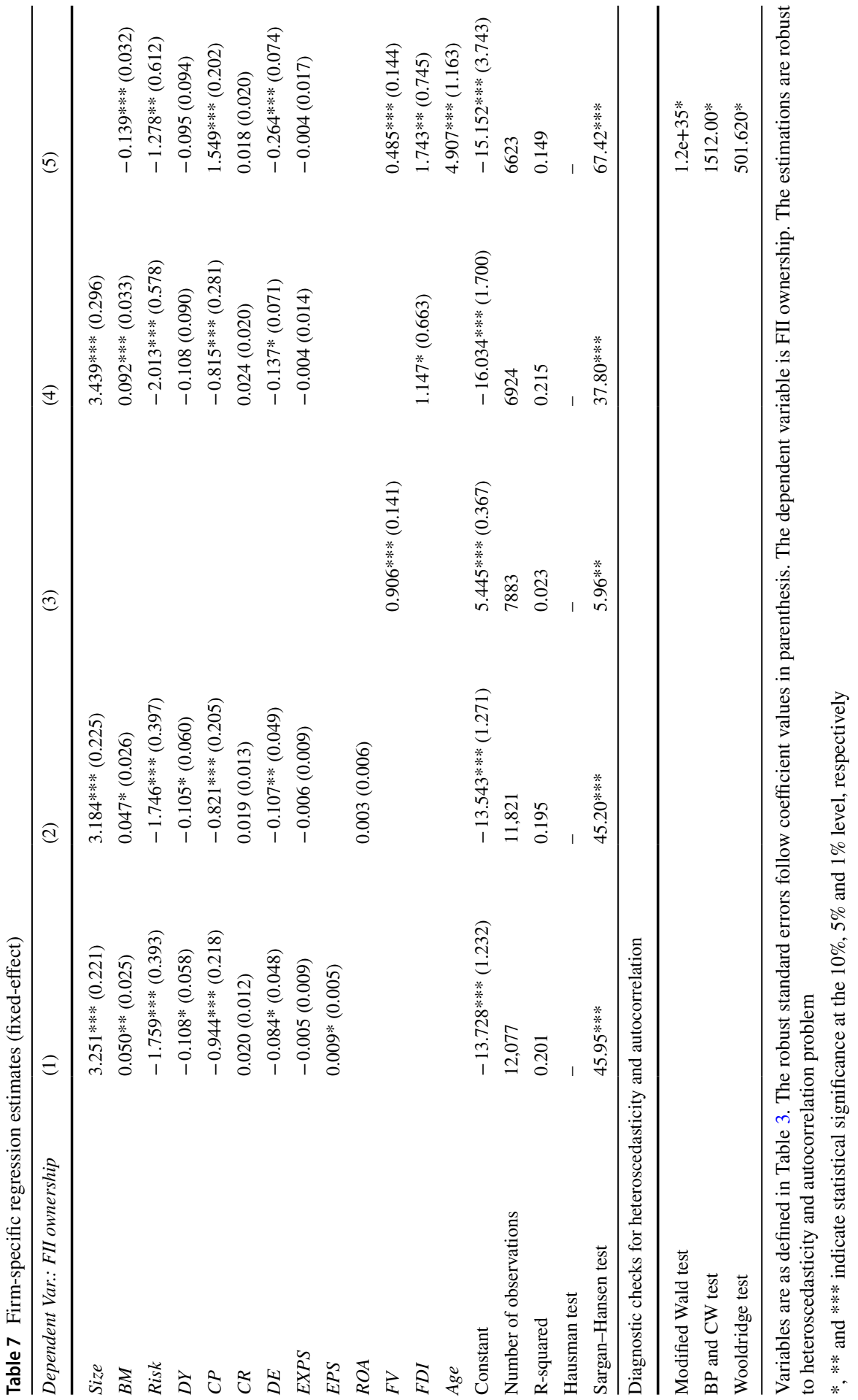


words, the foreign investment is a "smart investment," Thus, investors are required to identify those stocks that outperform stocks with higher expected returns forecasted by other investors (Gompers and Metrick 2001). The coefficient of liquidity ratio $(C R)$ is positive, suggesting that the foreign investors look for the firms' ability to meet the short-term obligation from the current assets. The result confirms the theoretical predictions (Amihud and Mendelson 1986) and recent evidence (Easley and O'Hara 2004). This result shows that foreign investors demand highly liquid stocks and do not like to be exposed to highly leveraged firms with potential returns. For instance, the FII investors hold more stocks in the firms with a higher working capital stock.

We find an inverse relationship between leverage (ratio of debt to equity) and foreign ownership of domestic stocks in India, and results are statistically significant in all the specifications. The increase in the debt to equity ratio of the firm implies that the firm is highly leveraged. Such performance would be uncertain, which in turn increases the idiosyncratic volatility (Black 1976). The inverse relationship between leverage and FII validates the pecking order theory. Kang and Stulz (1997) and Batten and Vo (2015) report a negative relationship and suggest that foreign investors prefer to invest in low leverage firms.

Further, we use earning per share (EPS) and return on assets (ROA) as a measure of the firm's performance, and our findings show that an increase in the firm's performance encourages more foreign investors to own such stocks. The coefficient of EPS is positive and significant as expected by the implied cost equity models of Claus and Thomas (2001) and Fama and French (2002). The relationship is consistent with the mainstream theoretical prediction and the previous finding of Phung and Mishra (2016) on the Vietnamese stock market. In other words, FIIs are attracted to profitable firms. The coefficient of $R O A$ is consistent with the argument that institutional investors invest in higher $R O A$ firms as they utilize assets efficiently to squeeze profit (Model 2, Table 7). Nevertheless, the result is statistically insignificant and contrasts the evidence on the Vietnamese market (Phung and Mishra 2016).

To test the role of a firm's visibility $(F V)$ in the decision of FII to invest in a stock, we use advertisement expenditure as a proxy to the visibility. The firm's visibility is measured based on advertisement expenditure, news coverage, and product usage. We hypothesize a positive relationship between FII ownership and the $F V$. The increasing expenditure on advertisement leads to more publicity and visibility and induce FII ownership. The coefficient of $F V$ is positive and significant (Model 3 and 5, Table 7) and validate Merton's (1987a, b) model. The foreign promoter ownership $(F D I)$ is another variable close to the visibility variable and argument of Merton $(1987 \mathrm{a}, \mathrm{b})$. We employ a dummy variable to represent the presence of $F D I$ in a firm. If the firm holds the foreign promoter ownership in the form of $F D I$ in total equity, we consider dummy as one and zero otherwise. We expect more FDI ownership to induce a significant share of FII in the firm's total equity. The results suggest a direct relationship between the FII ownership of domestic stocks and the presence of FDI as a promoter (Model 4-5, Table 7). Our evidence supports the argument of Edison and Warnock (2003) that the FII investors prefer to invest in those companies in which the peers have FDI ownership overcome the asymmetric information. The herd behavior (Kaminsky et al. 2001) and group identity (Coval and Moskowitz 
1999) hypotheses also draws further support from the present empirical evidence. However, we find EXP-another variable that indicates perceptibility statistically insignificant to influence FII ownership.

Age is a crucial factor in the equity investment decision of investors, especially in the presence of asymmetric information. The review of literature on age shows that financial performance is positively related to the firm's age (Coad et al. 2018). Consistent with the theory, we find a direct relationship between age and foreign ownership of stocks indicating preference of the global investors to the older firms over the newer firms (Model 5, Table 7). Our evidence is consistent with the argument that foreign investors choose the stocks of the established companies to overcome asymmetric information in emerging markets, and they prefer stable returns (Kang and Stulz 1997). This finding contrasts previous evidence of Patnaik and Shah (2008). The preference for older firms indicates FII's buy-side bias (see Grosyberg et al. 2013).

We carry out a sub-sample analysis to check the robustness and general applicability of the results. We estimate Eq. (1) for pre and post-GFC periods, and results are presented in Tables 8 and 9 of Appendix A. We find results consistent with the baseline results (Table 7) and conform to our inferences. We do not find a significant impact of the GFC on the relationship between FII ownership and firm-specific variables. Nonetheless, the coefficient values for post-GFC period are lower than those of the pre-GFC period, but the statistical difference between coefficients is not significant.

Jensen and Meckling (1976) and Shleifer and Vishny (1986) postulate a theoretical relationship between ownership structure and firm performance. The empirical evidence on foreign ownership and performance of the firms is mixed. However, such documented evidence is plausible when the ownership is large and long-term (Douma et al. 2006). The buying and selling by FIIs who are portfolio investors hardly influence firm-specific factors (Chhibber and Majumdar 1999; Gedajlovic et al. 2005). Due to restrictions, FIIs in India hold a fragmented stake in the firms (Tables 1 and 4). With such a lower proportion and dispersed ownership, FIIs play a reluctant role in monitoring and are thus less likely to influence the firms (Khanna and Palepu 2000; Shrivastav and Kalsie 2017). Hence, the results of this study are not affected by endogeneity and causality.

Nonetheless, in some instances, FII ownership itself may affect the firms' visibility with the presumption that the presence of FIIs leads to an increase in the firm's recognition, which positively influences the performance. We examine this possibility by estimating a panel vector autoregression (VAR) model. Moreover, panel VAR has the merit of allowing the cross-sectional dimension, which also controls for heterogeneity across the subjects and reinforces the robustness of the estimation. Panel VAR models are selected based on stability and information criteria. The information criteria such as modified Bayesian information criteria (MBIC), modified Akaike information criteria (MAIC), and modified Hannan-Quinn information criteria (HQIC) suggest lag of one (Table 10 of Appendix B). Eigenvalues confirm the stability of the panel VAR model (Table 11 and Fig. 6 of Appendix B). In a panel VAR, all variables are treated as endogenous, and explanatory variables assume lagged value to capture causality. The generalized moment estimation 
(GMM) method is used to estimate the panel VAR model. The estimators are consistent and asymptotically efficient. We impose Cholesky's orthogonal decomposition to estimate impulse-response functions (Figs. 7 and 8 of Appendix B). ${ }^{8}$

The panel VAR estimates confirm the inference drawn from the panel regression estimates of firm-specific determinants of the FII ownership of stocks in India. In other words, FII ownership is sensitive to a unit shock in firm-level variables (Fig. 7 of Appendix B). On the other hand, we find that firm's visibility and returns on assets are the only variables sensitive to the shock in FII ownership. The result suggests that while the firm's visibility attracts global investors, investment by the FIIs in a firm itself boosts the firm's visibility. ${ }^{9}$ The significant impact of the FII ownership on return on asset indicates that the firms utilize the assets better with the increased presence of global investors. Our evidence on the return on asset and foreign ownership is consistent with the view of Khanna and Palepu (2000) that the increased presence of global investors brings monitoring benefits, which leads to better utilization of assets. Overall, the empirical analysis shows that FII ownership primarily belongs to the theory of the firm and equity research.

\section{Corporate Governance and Foreign Ownership}

The growing body of literature on corporate governance shows the increasing influence of corporate governance on investment decisions (Gompers and Metrick 2001; Mohanty 2003; Gibson 2003; Morey et al. 2009; Mukherjee 2015). Bhagat and Black (1999) find an uncertain relationship between governance and performance of the firms. Brown and Caylor (2006) show the relevance of a few governance indicators to the firm's valuation. Similarly, Renders et al. (2010) empirically find decreasing marginal effect of governance on the valuation of European firms.

The best corporate governance mechanism protects the wealth of minority shareholders from agency problems (La Porta et al. 1999; Bokpin and Isshaq 2009 and Klapper and Love 2004). Hence, corporate governance indicators (CGIs) are expected to directly relate to the FII ownership because of their positive influence on performance of firms. Mangena and Tauringana (2007) show a positive association between disclosure, independent non-executive directors and audit committee, and foreign ownership of the stocks. However, Panicker et al. (2016) find no such relationship except the board's size in the IT industry.

In this light, we probe the influence of CGIs on the investment decision of FII to own stocks of Indian companies. The research on corporate governance is scarce, especially with panel framework, due to a lack of quality data on indicators (BörschSupan and Köke 2003; Sjöstrand 2016). The problem is more severe in emerging markets such as India. The data on several CGIs is not available at a firm-level for a meaningful estimation. We choose CGIs, such as board size $(B S)$, independent directors $(I D)$, and non-executive directors (Non-exe) for the analysis dedicated by

\footnotetext{
8 The supplementary statistics are available from the authors upon request.

9 We have estimated the Eq. (1) with and without ROA and visibility in models from 1 to 6 (Table 7).
} 
Table 8 Corporate governance indicators (CGI) and FII

\begin{tabular}{lllll}
\hline FII ownership & $(1)$ & $(2)$ & $(3)$ & $(4)$ \\
\hline BS & $-0.261(0.259)$ & $-0.201(0.258)$ & $-0.284(0.257)$ & $-0.179(0.251)$ \\
$I D$ & $1.395^{* * *}(0.537)$ & $1.202^{* *}(0.570)$ & $1.309^{* *}(0.524)$ & $1.227^{* *}(0.563)$ \\
Non-Exe & $0.582^{* * *}(0.261)$ & $0.461^{* * *}(0.211)$ & $0.405^{* *}(0.192)$ & $0.271^{* * *}(0.115)$ \\
GFC & & & $-1.784^{* * *}(0.514)$ & $1.352^{* *}(0.644)$ \\
Size & & $5.125^{* * *}(0.790)$ & & $5.813^{* * *}(0.864)$ \\
BM & & $0.616^{* * *}(0.102)$ & & $0.643^{* * *}(0.110)$ \\
Risk & $0.226(1.360)$ & & $0.284(1.347)$ \\
DY & $0.036(0.050)$ & & $0.034(0.049)$ \\
$C P$ & $-0.984(0.633)$ & & $-2.193^{* * *}(0.833)$ \\
$C R$ & & $-0.059(0.050)$ & & $-0.072(0.047)$ \\
DE & & $-0.486(0.326)$ & & $-0.518(0.314)$ \\
EXPS & & $-0.029(0.032)$ & & $-0.029(0.035)$ \\
EPS & & $0.011(0.031)$ & & $0.042^{* * *}(0.013)$ \\
ROA & & $0.267(0.353)$ & & $-0.007(0.034)$ \\
$F V$ & $-1.831(2.098)$ & & $0.313(0.355)$ \\
Constant & $11.472^{* * *}(1.006)$ & $-37.680^{* * *}(5.682)$ & $11.773^{* * *}(0.999)$ & $-40.071^{* * *}(5.756)$ \\
Number of Obs & 2239 & 1353 & 2239 & 1353 \\
R-squared & 0.009 & 0.271 & 0.019 & 0.282 \\
\hline
\end{tabular}

Variables as defined in Table 3. This table presents the panel fixed effect regression results of CGI indicators. In model 1, we include CGI variables, whereas, in model 2, these variables are added to the regressors (financial variables) of the baseline model of Table 6. We further estimate these models with the GFC dummy in model 3 and model 4, respectively. The corporate governance indicators $(B S, I D$, and Non-Exe) are collected from Bloomberg. For the 1078 total sample firms, the CGI data was available for 343 firms from 2006 to 2016

the availability of data. We estimate panel regression between FII ownership and these corporate governance variables (Model 1, Table 8). To ensure robustness, we also estimate a baseline regression (Eq. 1) with governance variables (Model 2, Table 8). ${ }^{10}$

The theoretical relationship between board size and foreign ownership of stocks is direct. The larger boards indicate the independence of the board (Muth and Donaldson 1998). CEOs need to build a consensus on a large size board and cannot dominate it. Some studies also report a negative relationship (Yermack 1996; Fich and Shivdasani 2005) owing to free rider and monitoring issues. Independent directors and non-executive directors reduce the likelihood of fraud and misuse of power (Dechow et al. 1996; Hillman and Dalziel 2003; Raheja 2005). The foreign investors perceive these directors as competent in monitoring the firm and ensuring the protection of investors. The non-executive directors are also expected to reduce agency

\footnotetext{
10 . Corporate governance may influence the financial performance of the firms. Nonetheless, the correlation matrix and VIF statistics do not show such possibilities. The regression estimate with and without financials in the CGI models further confirms it.
} 
costs and improve the monitoring and accountability of the boards (Zattoni et al. 2009). The empirical evidence on the issue is mixed.

The proxies of corporate governance are negatively skewed and non-normally distrusted (Table 4). These CGIs are not correlated with financial performance proxies and follow the stationary process (Tables 5 and 6). We find coefficients of $I D \&$ Non-Exe positive and statistically significant. The result implies that foreign investors choose to invest in stocks of those companies with more independent directors and non-executive numbers. These results are consistent with previous works such as Mangena and Tauringana (2007) and Desender et al. (2013) but contradict Panicker et al. (2016). The empirical evidence is consistent with the theoretical works, which illustrate that the composition and independence of the board lead to effective monitoring and accountability and eventually ensure the protection of the investors, especially the minority shareholders (Fama and Jensen 1983; Yermack 1996; Dechow et al. 1996; Fich and Shivdasani 2005; Raheja 2005; Zattoni et al. 2009). Our estimates indicate a negative relationship between board size and FII ownership, but the coefficient is statistically insignificant. The negative sign of the coefficient is consistent with some of the theoretical predictions that coordination, communication, and cohesiveness problems arise in large boards (Jensen 1993; Lipton and Lorsch 1992). The increase in board size also leads to a free-rider problem and lower corporate performance (Lipton and Lorsch 1992). Our finding on board size is consistent with Mangena and Tauringana's (2007) study but contrasts evidence of Panicker et al. (2016) for IT firms. To further check the robustness, we examine the impact of CGIs on FII ownership by re-estimating models 1 and 2 of Table 8 with the GFC dummy and present the estimates (Model 3 and 4) in the same table. ${ }^{11} \mathrm{We}$ do not find a significant difference between these estimates and full sample analysis. The estimates thus presented in Table 8 with various specifications show that the overall inference drawn on the relationship between CGIs and FII ownership is not sensitive to any chosen sample or events.

\section{Conclusion}

We investigate the determinants of foreign ownership of domestic stocks in the fastest-growing emerging markets such as India. The present research employs firmlevel data to investigate the significant determinants of foreign ownership in Indian stocks. We find firm-specific factors such as size, the book to market ratio, the volatility of the stock, stock price, dividend yield, liquidity, leverage, and earnings as primary determinants of foreign ownership. FIIs also factor in the corporate governance of the firms in their investment decisions. We find no evidence to show foreign investors as fair-weather friends. Instead, our empirical analysis shows that FIIs are smart investors who look for potential returns and follow a smart investment strategy consisting of top-down and bottom-up approaches of equity analysis. The findings

\footnotetext{
11 We cannot divide the sample into pre- and post-GFC due to lack of data for the pre-GFC period. The estimates for the post-GFC period are available upon request from the authors.
} 
call for reforms in corporate governance and a further improvement in companies' financial fundamentals to attract the FII.

Supplementary Information The online version contains supplementary material available at https://doi. org/10.1007/s40953-021-00233-3.

Acknowledgements We thank the anonymous reviewer for the most insightful comments and suggestions, especially the novel perspectives on corporate governance and alternative modeling. We especially thank the, Editor and staff of the journal for the flexible approach during the COVID-19 pandemic. The earlier versions of the paper were presented at 6th IIFT Conference on Empirical Issues in International Trade and Finance, New Delhi and International Conference on New Directions in Economic Theory and Empirical Economics, IIM Calcutta. The corresponding author thanks the SRIC IIT Kharagpur for the grants to carry out this project. Any errors are our own.

Funding The research is funded by Sponsored Research and Industrial Consultancy (SRIC), Indian Institute of Technology Kharagpur, Kharagpur, India.

\section{References}

Amihud, Y., and H. Mendelson. 1986. Asset pricing and the bid-ask spread. Journal of Financial Economics 17: 223-249.

Baltagi, B.H. 2021. Econometric analysis of panel data, 6th ed. New York: Wiley.

Baltagi, B.H., and C. Kao. 2001. Nonstationary panels, cointegration in panels and dynamic panels: a survey. In Nonstationary panels, panel cointegration, and dynamic panels, ed. B.H. Baltagi, T.B. Fomby, and H.R. Carter Hill. Emerald Group Publishing Limited: Bingley.

Batten, J.A., and X.V. Vo. 2015. Foreign ownership in emerging stock markets. Journal of Multinational Financial Management 32: 15-24.

Bebchuk, L., A. Cohen, and A. Ferrell. 2009. What matters in corporate governance? The Review of Financial Studies 22 (2): 783-827.

Bhagat, S., and B. Black. 1999. The uncertain relationship between board composition and firm performance. The Business Lawyer 54 (3): 921-963.

Black, F. 1976. Studies of stock price volatility changes. In Proceedings of the 1976 meetings of the American statistical association, 171-181.

Bokpin, G.A., and Z. Isshaq. 2009. Corporate governance, disclosure and foreign share ownership on the Ghana Stock Exchange. Managerial Auditing Journal 24 (7): 688-703.

Börsch-Supan, A., and J. Köke. 2003. An applied econometricians' view of empirical corporate governance studies. German Economic Review 3 (3): 296-326.

Brealey, R., S. Myers, and F. Allen. 2017. Corporate finance. New York: McGraw Hill.

Brennan, M., and A. Subrahmanyam. 1996. Market microstructure and asset pricing; on the compensation of illiquidity in stock returns. Journal of Financial Economics 41: 441-464.

Brown, L.D., and M.L. Caylor. 2006. Corporate governance and firm valuation. Journal of Accounting and Public Policy 25: 409-434.

Chhibber, P.K., and S.K. Majumdar. 1999. Foreign ownership and profitability: property rights: control and the performance of firms in Indian industry. The Journal of Law and Economics 42 (1): 209-238.

Claus, J., and J. Thomas. 2001. Equity premia as low as three percent? Evidence from analysts' earnings forecasts for domestic and international stock markets. The Journal of Finance 56 (5): 1629-1665.

Coad, A., J.R. Holm, J. Krafft, and F. Quatraro. 2018. Firm age and performance. Journal of Evolutionary Economics 28: 1-11.

Coval, J., and T. Moskowitz. 1999. Home bias at home: local equity preference in domestic portfolios. Journal of Finance 54 (6): 2045-2073.

Dahlquist, M., and G. Robertsson. 2001. Direct foreign ownership, institutional investors, and firm characteristics. Journal of Financial Economics 59 (3): 413-440. 
Dechow, P.M., R.G. Sloan, and A.P. Sweeney. 1996. Causes and consequences of earnings manipulation: an analysis of firms subject to enforcement actions by the SEC. Contemporary Accounting Research 13: $1-36$

Desender, K.A., R.V. Aguilera, R. Crespi, and M. GarcÍa-cestona. 2013. When does ownership matter? Board characteristics and behavior. Strategic Management Journal 34 (7): 823-842.

Devereux, M., and F. Schiantarelli. 1990. Investment, financial factors and cash flow: evidence from UK panel data. Working Paper. Cambridge: National Bureau of Economic Research.

Dhamija, N. 2008. Foreign institutional investment in India: an exploratory analysis of patterns across firms. Margin: The Journal of Applied Economic Research 2 (3): 287-320.

Douma, S., R. George, and R. Kabir. 2006. Foreign and domestic ownership, business groups, and firm performance: evidence from a large emerging market. Strategic Management Journal 27 (7): 637-657.

Easley, D., and M. O'Hara. 2004. Information and the cost of capital. The Journal of Finance 59: 1553-1583.

Edison, H., and F. Warnock. 2003. U.S. Investors' emerging market equity portoflios: a security-level analysis. IMF Working Paper WP/03/238.

Fama, E.F., and K.R. French. 1992. The cross-section of expected stock returns. Journal of Finance 47 (2): 427-465.

Fama, E.F., and K.R. French. 1995a. Size and book-to-market factors in earnings and returns. Journal of Finance 50 (1): 131-155.

Fama, E.F., and K.R. French. 1995b. Size and book-to-market factors in earnings and returns. The Journal of Finance 50 (1): 131-155.

Fama, E.F., and K.R. French. 2002. The equity premium. The Journal of Finance 57 (2): 637-659.

Fama, E.F., and M.C. Jensen. 1983. Separation of ownership and control. Journal of Law and Economics 26: 301-326.

Fich, E.M., and A. Shivdasani. 2005. The impact of stock-option compensation for outside directors on firm value. The Journal of Business 78 (6): 2229-2254.

French, K.R., and J.M. Poterba. 1991. Investor diversification and international equity markets. American Economic Review 81 (2): 222-226.

Froot, K.A., P.G. O'connell, and M.S. Seasholes. 2001. The portfolio flows of international investors. Journal of Financial Economics 59 (2): 151-193.

Furman, J., J.E. Stiglitz, B.P. Bosworth, and S. Radelet. 1998. Economic crises: evidence and insights from East Asia. Brookings papers on economic activity 2. https://www.brookings.edu/wp-content/ uploads/1998/06/1998b_bpea_furman_stiglitz_bosworth_radelet.pdf.

Galo, A. 2016. A refresher on return on assets and return on equity. Harvard Business Review. https://hbr. org/2016/04/a-refresher-on-return-on-assets-and-return-on-equity.

Gedajlovic, E., T. Yoshikawa, and M. Hashimoto. 2005. Ownership structure, investment behaviour and firm performance in Japanese manufacturing industries. Organization Studies 26 (1): 7-35.

Gibson, M.S. 2003. Is corporate governance ineffective in emerging markets? Journal of Financial and Quantitative Analysis 38 (1): 98-195.

Gompers, P.A., and A. Metrick. 2001. Institutional investors and equity prices. The Quarterly Journal of Economics 116 (1): 229-259.

Grosyberg, B., P. Healy, and G. Serafeim. 2013. The stock selection and performance of buy-side analysts. Management Science 59 (5): 1062-1075.

Gupta, M.P., and M.J.P. Gordon. 2003. Portfolio flows into India: do domestic fundamentals matter? IMF Staff Papers 3 (20): 555-582.

Hansen, L.P. 1982. Large sample properties of generalized method of moments estimators. Econometrica 50: 1029-1054.

Hausman, J.A. 1978. Specification tests in econometrics. Econometrica 46 (6): 1251-1271.

Hillman, A., and T. Dalziel. 2003. Boards of directors and firm performance: integrating agency and resource dependence perspectives. Academy of Management Review 28 (3): 383-396.

Hiremath, G.S. 2017. Macroeconomics and markets in developing and emerging economies by Ashima Goyal. Journal of Quantitative Economics 16: 309-312.

Hsiao, C. 2007. Panel data analysis—advantages and challenges. Test 16 (1): 1-22.

Hsiao, C. 2014. Analysis of panel data. Cambridge: Cambridge University Press.

Huberman, G. 2001. Familiarity breeds investment. The Review of Financial Studies 14 (3): 659-680.

Jensen, M.C. 1993. The modern industrial revolution, exit, and the failure of internal control systems. The Journal of Finance 48: 831-880. 
Jensen, M.C., and W.H. Meckling. 1976. Theory of the firm: managerial behavior, agency costs and ownership structure. Journal of Financial Economics 3: 305-360.

Kadapakkam, P.-R., P.C. Kumar, and L.A. Riddick. 1998. The impact of cash flows and firm size on investment: the international evidence. Journal of Banking and Finance 22: 293-320.

Kaminsky, G.L., R.K. Lyons, and S.L. Schmukler. 2001. Mutual fund investment in emerging markets: an overview. Policy Research Working Paper 2529. World Bank Development Research Group, World Bank.

Kang, Jun-Koo., and R. Stulz. 1997. Why is there a home bias? An analysis of foreign portfolio equity ownership in Japan. Journal of Financial Economics 46 (1): 3-28.

Khanna, T., and K. Palepu. 2000. Emerging market business groups, foreign intermediaries, and corporate governance. In Concentrated corporate ownership, ed. R.K. Morck. Chicago: University of Chicago Press.

Khanna, T., K. Palepu, and K. Carlsson. 2005. Portfolio investment in emerging market review. Boston: Harvard Business School.

Klapper, L.F., and I. Love. 2004. Corporate governance, investor protection, and performance in emerging markets. Journal of Corporate Finance 10 (5): 703-728.

LaPorta, R., F.L. de Silanes, and A. Shleifer. 1999. Corporate ownership around the world. The Journal of Finance 54: 471-517.

Liljeblom, E., and A. Löflund. 2005. Determinants of international portfolio investment flows to a small market: empirical evidence. Journal of Multinational Financial Management 15 (3): 211-233.

Lin, C.H., and C.Y. Shiu. 2003. Foreign ownership in the Taiwan stock market-an empirical analysis. Journal of Multinational Financial Management 13 (1): 19-41.

Lintner, J. 1965. The valuation of risky assets and the selection of risky investments in stock portfolios and capital budgets. Review of Economics and Statistics 47: 13-37.

Lipton, M., and J.W. Lorsch. 1992. A modest proposal for improved corporate governance. Business Lawyer 48: 59-77.

Mangena, M., and V. Tauringana. 2007. Disclosure, corporate governance and foreign share ownership on the Zimbabwe stock exchange. Journal of International Financial Management and Accounting 18 (2): 53-85.

McKinsey. 2002. Global investors opinion survey. McKinsey \& Company. www.mckinsey.com/gover nance.

Merton, R.C. 1987a. A simple model of capital market equilibrium with incomplete information. The Journal of Finance 42 (3): 483-510.

Merton, R.C. 1987b. A simple model of capital market equilibrium with incomplete information. The Journal of Finance 42 (483): 510.

Miller, M., and F. Modigliani. 1961. Dividend policy, growth, and the valuation of shares. The Journal of Business 34: 411-433.

Modigliani, F., and M.H. Miller. 1958. The cost of capital, corporation finance and the theory of investment. The American Economic Review 48 (3): 261-297.

Mohanty, P. 2003. Institutional investors and corporate governance in India National Stock Exchange of India Research Initiative Paper No. 15. https://ssrn.com/abstract=353820.

Morey, M., A. Gottesman, E. Baker, and B. Godridge. 2009. Does better corporate governance result in higher valuations in emerging markets? Another examination using a new data set. Journal of Banking \& Finance 33 (2): 254-262.

Mukherjee, R. 2015. Institutions, corporate governance and capital flows. Journal of International Economics 96 (2): 338-359.

Muth, M.M., and L. Donaldson. 1998. Stewardship theory and board structure: a contingency approach. Corporate Governance: An International Review 6 (1): 5-28.

Panicker, V.S., S. Mitra, and R. Sensarma. 2016. Corporate governance determinants of FII in Indian IT firms. Indian Journal of Corporate Governance 9 (1): 1-18.

Patnaik, I., and A. Shah. 2008. Investment decisions of foreign investors and domestic institutional investors. Working Paper, September. National Institute of Public Finance and Policy.

Phung, D.N., and A.V. Mishra. 2016. Ownership structure and firm performance: evidence from Vietnamese listed firms. Australian Economic Papers 55 (1): 63-98.

Raheja, C.G. 2005. Determinants of board size and composition: a theory of corporate boards. Journal of Financial and Quantitative Analysis 40 (2): 283-306. 
Renders, A., A. Gaeremynck, and P. Sercu. 2006. Corporate governance and performance: controlling for sample selection bias and endogeneity. Working Paper, K.U. Leuven AFI Working Paper No. 0606, Available at SSRN: https://ssrn.com/abstract=888770.

Renders, A., A. Gaeremynck, and P. Sercu. 2010. Corporate-governance ratings and company performance: a cross-European study. Corporate Governance: An International Review 18 (2): 87-106.

Richards, A. 2005. Big fish in small ponds: the trading behavior and price impact of foreign investors in Asian emerging equity markets. Journal of Financial and Quantitative Analysis 40 (1): 1-27.

Sargan, J.D. 1958. The estimation of economic relationships using instrumental variables. Econometrica 26: 393-415.

Sharma, R. 2002. Indian markets character problem. Economic Times, June 10.

Sharpe, W.F. 1964. Capital asset prices: a theory of market equilibrium under conditions of risk. The Journal of Finance 19: 425-442.

Shleifer, A.R., and R. Vishny. 1986. Large shareholders and corporate control. Journal of Political Economy 94: 461-488.

Shrivastav, S.M., and A. Kalsie. 2017. The relationship between foreign ownership and firm performance in India: an empirical analysis. Artha Vijnana 59: 152-162.

Sjöstrand, Sven-Erik. 2016. Rethinking corporate governance. Northampton: Edward Elgar.

Solnik, B.H. 1974. Why not diversify internationally rather than domestically? Financial Analysts Journal 30 (4): 48-54.

Sul, D. 2019. Panel data econometrics: common factor analysis for empirical researchers, 1st ed. New York: Routledge.

Taylor, M., and L. Sarno. 1997. Capital flows to developing countries: long- and short-term determinants. World Bank Economic Review 11 (3): 451-470.

Verbeek, M.J.C.M., and T.E. Nijman, 1996. Incomplete panels and selection bias: A survey. Center for Economic Research, Tilburg University.

Verbeek, M. 2021. Panel methods for finance: a guide to panel data econometrics for financial applications. Rotterdam: De Gruyter.

Wooldridge, J.M. 2010. Econometric analysis of cross section and panel data, 2nd ed. Cambridge: MIT Press.

Yermack, D. 1996. Higher market valuation of firms with a small board of directors. Journal of Financial Economics 40: 185-211.

Zattoni, A., T. Pedersen, and V. Kumar. 2009. The performance of group-affiliated firms during institutional transition: a longitudinal study of Indian firms. Corporate Governance: An International Review 17 (4): 510-523.

Publisher's Note Springer Nature remains neutral with regard to jurisdictional claims in published maps and institutional affiliations. 